MODERNISM AND MAGIC 
Edinburgh Critical Studies in Modernist Culture

Series Editors: Tim Armstrong and Rebecca Beasley

\section{Forthcoming Series Volumes:}

Modernism and Magic: Experiments with Spiritualism, Theosophy and the Occult, Leigh Wilson

Sonic Modernity: Representing Sound in Literature, Culture and the Arts, Sam Halliday

Modernism and the Frankfurt School, Tyrus Miller

Late Modernism, Laura Salisbury

Modernism, Space and the City, Andrew Thacker

Modernism and the Idea of Everyday Life, Leena Kore-Schroder 


\title{
MODERNISM AND MAGIC
}

\author{
Experiments with Spiritualism, \\ Theosophy and the Occult
}

\author{
Leigh Wilson
}


For my parents, with love, and in loving memory of Helen Litt

(C) Leigh Wilson, 2013

Edinburgh University Press Ltd

22 George Square, Edinburgh EH8 9LF

www.euppublishing.com

Typeset in Sabon and Gill Sans

by Servis Filmsetting Ltd, Stockport, Cheshire, and printed and bound in Great Britain by CPI Group (UK) Ltd, Croydon CR0 4YY

A CIP record for this book is available from the British Library

ISBN 9780748627691 (hardback)

ISBN 9780748631650 (webready PDF)

ISBN 9780748672332 (epub)

ISBN 9780748672349 (Amazon ebook)

The right of Leigh Wilson

to be identified as author of this work

has been asserted in accordance with

the Copyright, Designs and Patents Act 1988. 